\title{
THE PROBLEM OF PERFORMANCE TYPOLOGY: THE CASE OF SERBIAN MOURNERS
}

\section{OKSANA MYKYTENKO}

This paper analyzes the performance process of Serbian mourning songs (tužbalice) and various ethnic and folklore conditions of the functional process of this genre.

Keywords: mourning songs, performance, ritual folklore, epic tradition
Vprispevku avtorica analizira postopke izvajanja srbskih žalostink (tužbalice) glede na različne etnične in folklorne okolišcine funkcionalnega procesa $v$ tem žanru kot tudi glavnih značilnosti žanra.

Ključne besede: naricalke, uprizoritev, ritual, epska tradicija

Funeral lamentation continues to be a creative genre of traditional ritual folklore that is still part of the living folk tradition in some South Slavic regions that is organically included in modern life and maintains a special existence and continuity within folk tradition.

Using available examples of contemporary funeral laments, it is interesting to retrace the interaction and interdependence of genre indicators as a specific manifestation of their uniqueness in the historical and folk process. Proceeding from the definition of folk genre as "a whole set of works that are characterized by a community of poetic system, life purposes, form of performance, and musical harmony" (Propp 1964: 58), it is possible to define the typological features of performance of these folk lyrics.

In the living heritage of mourning traditions, the presence of creatively gifted performers that express their individuality is naturally determined. The lyrics of mourning songs are marked by distinctive structural and morphological indicators and have appropriate functional and semantic features, and so they depend on the performance skills of the mourner. Taking into account the psychological traits of mourners, the nature of performance of the work, and the creative capabilities and life experience of the performer, it is possible to determine several types of performers and, accordingly, several categories of lyrics.

First, there are lyrics that are created during the ceremony at the time of the highest emotional stress, when feelings are given the most complete form of expression. Later, the consciousness of the performer retains only commonplace details, sometimes little related to one another. The next day, she often forgets what she sang the day before, or, as asserted by Karadžić, she cannot recall "even every tenth word" (1977: 192). Such laments are created mainly for those that perform them and have an exclusively everyday family purpose. Their meaning is literally embodied in their performance; in general, the lyrics may be very short or very long, but in either case they consist of clichéd formulas and phrases that are 
repeated. Such is, for example, the mourning song by a four-year-old girl for her father, as reported by Vukanović (1972: 191).

Second, there are lyrics that are created by the performers, whose repertoire is broader and more stable and is also associated with personal emotional experiences. In this case, mourners try to fill the traditional pattern of motifs with autobiographical facts. In these songs of sorrow only female family members can praise the deceased. In performing these touching laments, the mourner "then mentions other dead relatives, then the family and homeland, and finally godparents, friends, and acquaintances" (Šaulić 1929: 17). These laments are "songs of pain of heart and pride, through which the deceased is protected from death, non-existence, and oblivion" (Šaulić 1929: 16). Such works do not require an audience as an obligatory prerequisite, although they are ordinarily directed to those present. The lyrics of such lamentations are monologues by those that deeply and sincerely suffer, and here the traditional compositional outline is filled with specific content. In recording such lyrics, Šaulić noticed that, depending on individual characteristics, some mourners improvise their laments, whereas others at first consider and create the lyrics in silence. The function of psychological comfort is the main factor for such lyrics: "When I'm alone, I retreat into my sorrow and grief and begin to mourn for hours, and do it until someone interrupts me". If the mourner does not "communicate in such a way" with the dead, "she could not stand it"; if she does communicate, she begins to feel better, Šaulić notes. No wonder that people have long said kukam da muku oteram 'I cry to drive the pain away'Third, a separate group forms the lyrics of those mourners whose skills are generally recognized and well known. The power of their poetic talent in creating laments is equal to the praise of heroes by "gusle" players. The aspiration for objective representation and the desire for greater social significance are manifested in the breaking of the purely weeping tradition, when motifs of struggle and revenge or tones of irony or sarcasm are added to the lyrics. Performers of such works realize the independent artistic value of their laments, and a spirit of competition can occur among them. In this living tradition of mourning and teaching mourning, there is a general recognition of lyrics created by mourners whose skills are widely known. According to Vukanović,

some mourners [were] offended if they knew that somebody else mourned for me, someone from a lower social stratum. After that they only occasionally agreed to mourn. ... Someone said to me "Do not confuse them with other persons because they do not want to be like others." (Vukanović 1972: 17)

Such mourners are also able to mourn without seeing — by feeling — that is, without knowing the deceased during his or her lifetime.

Traditional perceptions in this case regulate the correlation between traditional and improvisational elements, and this acts as a factor that supports the continuity of tradition with inherent performance standards. Thus, if for a mourner mourning is all that comes to mind, it is said that is she began to "wag her tongue." In mourning it is also not allowed to mourn without desire, without feelings (premizgivanje), because then people say that the mourner is just making a racket (dandara). Poetically expressive lyrics find response among 
the audience, even if the mourner has no special vocal talent. The skills of the mourners are shown in such cases when traditional genre norms and devices are inadequate, and the circumstances require changes in the conventions of mourning (Kilibarda 1980: 95).

There have been many poetically gifted performers among young heroes and "gusle" players. The people's "oral poets," as they were called by Šaulić (p.c.), bemoan the departed "with a feeling of love and heroism," creating highly emotional laments, brilliant in artistic and picturesque images. Each of them, for an only son, or for a brother, or for heroes, maintained pride for the fallen as well as grief. In their works, these "oral poets" not only supported the living but also preserved the memories of the fallen. It was said about such mourners that "to listen to them is lovelier than any gusle player: they glorify miracles" (Šaulić). The culmination of such lyrics celebrates the name of the hero and expresses pride in him. Even after many years, these mourners are filled with vivid memories about the deceased and create impressive, strong mourning songs, citing the names of living heroes. These mourners are not just creating a conversation, the usual ceremonial mourning, but with the mourning "they aggravate wounds on their hearts" (Šaulić) and assert the glory of the brothers of their nation. The main body of such laments is related to the principles of collecting activity (and not only in Serbian folklore studies), which is mainly aimed at recording the best performers. However, as noted by the Russian researcher Kharitonova, who analyzed genre variations of East Slavic traditions of mourning, "material recorded from this type of informant is on the periphery of actual folklore" (1987: 147).

Systematizing the lyrics cited by Šaulić, Đaković, Vukanović, Kilibarda, and others is very important and interesting. The images of mourners that arise, especially in the articles by Šaulić, elucidate the ways the laments are created and psychological characteristics of the performers. Šaulić was born in Montenegro and was personally acquainted with many of the performers. In the early twentieth century, when he started his collecting work, he announced his democratic objective to record the creative heritage of ordinary illiterate women, and he remained faithful to this principle throughout his research activities. The best recognition of this work, to which he dedicated his life, are the words of the seventyyear-old mourner Đurđa Lakušić, as reported by the researcher: "She met me with cold and dignity and said that I had come to her for nothing because 'her sorrow had died out long ago.' But when she heard my name (she knew many of my relatives and she was aware that I record laments), she said: 'Even if I were dead I would rise from my coffin to mourn the grief of my heart and my sorrow for heroes. It is sad for me that I did not know the brother and the son, who come to me, a poor old woman" (Šaulić 1959: 375). It should be added that Šaulićs collecting activities were known among the people, and the mourners were proud that their songs were saved for their descendants. It should also be noted that, even in our time, mourners are "largely half-educated or illiterate women." Thus, according to some, old Savka Stojković (who died in 1998) entrusted a relative to mourn for her because her daughters were educated and "cannot mourn me" (Zlatanović 1999: 105). 
Fourth, among the creatively gifted performers, researchers have repeatedly distinguished professional mourners. Talented masters are not isolated and are mentioned in various Serbian and Montenegrin regions. Thus, Marko Miljanov wrote about "Neda, the wife of Jura Martinov from Medun," stressing that people were gathered around her like a good gusle player (Đorđević 1938: 186). Šaulić tells about “one of the best," Krstina Krstajić from Javorje (Šaulić 1953: 317). Vukanović identified "the profession of mourning" in Kosovo (1972: 14). Often the performers of such lyrics also skillfully perform epic songs that are by rule exclusively male affairs. The number of recognized mourners seems to increase on the basis of the developed epic tradition of the region.

Such poems of lamentation create a certain tradition or school and later become an example to follow. If a known lament for Batrićs sister from The Mountain Wreath by Petar Njegoš has become a literary and folk model, then the actual folklore lyrics of mourners of different social status at different times (e.g., laments for the Montenegrin Queen Consort Milena Petrović Vukotić or for her daughter, Princess Zorka Karađorđević) became familiar songs and existed in many variants. In addition, some fragments of these lyrics were memorized and performed independently. So far these examples are not numerous, but they are considered especially valuable and demonstrate the genre transition from mourning to epic poetry. In drawing parallels between laments and epic songs, one inevitably moves away from the ritual dominant in mourning. However, it is those that differ from traditional mourning within the ritual that have features that attracted the interest of almost all researchers of mourning songs. Thus, a contemporary of Karadžić, Vuk Vrčević, who brought folk mourning to the attention of the outstanding scholar, noted that they "grieve only for men and boys," and the rest of the laments he called jekavice or naricanje 'lamentations' because of the lack of the motif of "glory." In his collection of folk mourning songs, Šaulić stresses that mourning songs and epic songs are associated through a joint plot. Interestingly, Vrčević noticed the same thing much earlier: "The poetic spirit [of mourning songs] in any case is not inferior to heroic folk songs, with the only difference that the women mourning, and the men accompanying on the gusle, glorify the fallen heroes. The first is a real folk chronicle, and the second is history”. (Pešić 1967: 186)

The figure of folk gusle players and artists is now in the past, although often their performances can be found during folk holidays and at festivals. In contrast, mourners can be heard in almost every region even today. Previously, with the "circle" of mourners at folk festivals, especially at dedication days, there were gusle players in the vicinity of the circle, and the mourner and the gusle player competed in poetic skill before a wide audience.

However, it should be noted that, according to many collectors and researchers, mourning songs were not exclusively a women's domain. Šaulić repeatedly encountered men performing mourning songs. Describing such cases in detail, he stated that women very rarely sing to the accompaniment of the gusle, but it is even rarer that men mourn because it is believed that it is not good for men to do so. 
Matija Murko discusses women as performers of epic songs (1951: 193-203). In contrast, Vukanović writes about laments in men's performance beyond their existence in ritual. In 1967 Dušan Nedeljković recorded a mourning song for his only son from a gusle player, the folk singer Milutin Vuković from Šćepan-Polje (Nedeljković 1967: 189). It is significant that one family could be proud of their recognized gusle players and their talented mourners. Thus, Šaulić writes about the family tradition of poetic skills, whose mourner Milica Obradović was the daughter of a "good" gusle player and the granddaughter of a "great" gusleone. From Milica's father Radovan, Šaulić recorded the epic song "The Death of Smail-aga Čengić," which was played and sang earlier by Milica’s grandfather, Šaban.

The heroic and patriotic performance of traditional mourning songs naturally also became the point of reference for this genre for gusle players. Šaulić illustrates this point: when a famous gusle player that had recently lost his son was asked to sing to the accompaniment of the gusle, instead of the expected heroic song, he poured out his sorrow in a mourning song. Interestingly, in such cases, when gusle players turned to the poetic form of a mourning song, it proceeded differently from the weeping form of the epic introduction, and only after a set of initial 10/12 syllable lines did such song-lamentation proceed into the consecutive traditional measures of a mourning song in an eight-syllable style.

On the other hand, some mourning songs in women's performance often can be considered epic songs rather than laments, the category to which they belong emotionally, artistically, and thematically. In this case, only the eight-syllable style defines the genre of the lyrics. The question of mourners' imitation of gusle players contains many mysteries, such as Šaulićs statement about the "transformation of a mourning song into a small epic song," in which a measure of verse (iambic decasyllable) and a formulaic composite construction create a set specific to the genre epithets and other poetic devices that are typical features of heroic songs.

Understanding the performing nature of folk art strengthens the awareness of the direct dependence of artistic qualities of the lyrics and their content on the special features of the performance (Britsyna 2006: 180). Historical, national, artistic, and poetic traditions in the development of epic and ritual folklore in Serbian and Montenegrin traditions led to the development of laments - mourning songs — as a distinctive genre of folk song creativity that has certain features of content, poetics, and performance. Song-laments as a historically conditioned form of art and poetry reveal regularities that are inherent to the genres of folklore in this Slavic ethno-cultural region, with definite parallels to other Slavic and non-Slavic traditions. However, this is a topic for another paper.

\section{REFERENCES}

Britsyna, Oleksandra

2006 Ukrayinska usna tradycijna proza. Pytannya tekstolohiyi ta vykonavstva. Kyyiv: NAN Ukrayiny, In-t mystectvoznavstva, fol"klorystyky ta etnolohiyi im.M.T. Ryl"s"koho. 
Đorđević, Tihomir

1938 Nekoliki samrtni običaji u Južnih Slovena. Godišnjica Nikole Čunića. Knj. 47: 153-191.

Kharitonova, Valentina

1987 Vostochnoslavjanskaja prichet' i ee ispolniteli. Fol'klor narodov RSFSR. Ufa: Izd. Bashkirskogo gos. un-ta, 139-148.

Karadžić, Vuk St.

1977 Crna Gora i Boka Kotorska. Beograd: Novo pokolenje.

Kilibarda, Novak

1980 Na marginama poetike narodnih tužbalica. Zora govora: Ka poetici usmenogpesništva. Niš: Gradina, 92-104.

Murko, Matija

1951 Tragom srpsko-hrvatske narodne epike: Putovanja u godinama 1930-1932. Zagreb: JAZU. Knj. 1.

Nedeljković, Dušan

1967 Tužbalica za sinom jedincem. Od guslara narodnog pesnika Milutina Vukovića sa Šćepan-rolja zabeležio dr. Dušan Nedeljković. Narodno stvaralaštvo-Folklor 6(22-24): 189-195.

Pešić, Radmila

1967 Vuk Vrčević. Filološki fakulet Beogradskog univerziteta. Knj.14.

Propp, Vladimir

1964 Zhanrovyj sostav russkogo fol'klora. Russkaja literatura. № 4, 58-76.

Šaulić, Novica

1929 Predgovor. Srpske narodne tužbalice. Beograd: Grafički institut.

Vukanović, Tatomir

1972 Narodne tužbalice. Folklorna gradja sabrana u Srba poreklom iz Crne Gore na Kosovu u Kosanucu. Vranje: Narodni muzej.

Zlatanović, Milivoje

1999 Tužbalica u Južnoj Srbiji. Etno-kulturološki zb. Za proučavanje kulture istočne Srbije i susednih oblasti. Svrljig. Knj. 5: 103-107.

\section{VPRAŠANJE TIPOLOGIJE IZVAJANJA. PRIMER SRBSKIH NARICALK}

Vprispevku smo analizirali postopke izvajanja srbskih žalostink (tužbalice). Različne etnične in folklorne okoliščine funkcionalnega procesa $v$ tem žanru kot tudi glavnih značilnosti žanra smo analizirali glede na stiri glavne kategorije besedil in štiri glavne vrste izvajalcev. Mojstrstvo žalujočega pri izvedbi, v katerem se kaže močna epska tradicija regije, zaznamuje proces prestopanja meja rituala. Omenjeni žanr predstavlja izjemen ljudski pojav, ki se nanaša na dve ravni ljudske poetične ustvarjalnosti: petje in žalovanje.

Dr. Oksana Mykytenko, Institute of Art Studies, Folklore and Ethnology of the National Academy of Sciences of Ukraine, 4 Hrushewsky St., Kiev 01001, Ukraine, oksana_mykytenko@hotmail.com 